\title{
ARTICLE
}

\section{The (Un)Heavenly Chorus in British Politics: Bringing the What, the When and the How Questions into the Analysis of Interest Group Influence}

\author{
Matia Vannoni \\ School of Public Policy, University College London
}

\begin{abstract}
Increasing attention has been paid to interest group influence in the last decades. Nonetheless, the literature has hitherto theoretically and analytically focused on who exerts influence overlooking on what, when and how influence is exerted. By replicating the analysis in Bernhagen (2009) this works aims to bring the what, when and how questions back into the analysis of interest group influence. In doing so, I provide a more nuanced discussion on politics as being 'about who gets what, when and how' (Lasswell, 1936). Aloof from any pretence of conclusiveness, preliminary findings show that not only are those questions worth of investigation per se but also that they potentially have a strong impact on the who question.
\end{abstract}

\section{Introduction}

This work aims to raise awareness in the literature on interest representation on three key questions: how, when and on what interest groups exert influence. In doing so, I take as an example and replicate the analysis in Bernhagen (2012) which investigates the influence interest groups exert on British policy-making. I complement that article by starting from the very same aphorism from which the of that work title is taken: 'politics is about who gets what, when and how' (Lasswell, 1936). Apart from few notable exceptions the mainstream approach to interest group influence has hitherto focused on the who question relegating the what, the when and the how ones to the side. Building on the traditional debate between elitism and pluralism in the American social sciences I argue that the analysis of interest group influence must look also at the second face of power (Bachrach and Baratz, 1962) as an alternative manner in which interest groups influence the decision-making process (i.e. the how question). Then, by building on various strands of the public policy literature I argue for the relevance of the policy typology (i.e. the what question) and the policy stage (i.e. the when question). In the last section I propose a preliminary (and mainly provocative) analysis based on the replication of the one conducted in Bernhagen (2012) ${ }^{1}$. I conclude by emphasising that not only are the what, the when and the how questions worth of attention per se but also that they potentially have a strong impact on the who question. In fact, by relying on the same mode of causal inference hitherto underpinned by the literature the preliminary findings drawn below question the portrait of British politics in the analysis in Bernhagen (2012) suggesting instead that 'the heavenly chorus sings with a strong upper class accent' (Schattsschneider, 1975 p.35).

\section{The Who Question}

Throughout the last decades the mainstream literature on interest representation has argued for the success of powerful and concentrated interests. Although diverging perspectives may be found what I label the private interest claim, namely the bodies of literature claiming the success of

\footnotetext{
${ }^{1}$ I owe my gratitude to Prof. Bernhagen for providing the replication codes and for commenting on a previous draft of this work. The dataset is publicly available at http://discover.ukdataservice.ac.uk/catalogue/?sn=6651\&type=Data\%20catalogue.
} 
private interests, has been predominant in political science. This claim stems from two almost paradigmatic accounts: Olson's $(1965,1982)$ logic of collective action and the capture theory of the 1970s and 1980s.

\section{The Private Interest Claim}

In his masterpiece The Logic of Collective Action Olson (1965) makes a bold claim: rational individuals need incentives to organise into interest groups. Olson $(1965,1982)$ argues that rational actors agree on a definition of the common interest to further and organise only if they are sufficiently few in number or they have strong individual incentives to organise. In other words, concentrated interests manage to mobilise and act at political level whilst diffuse ones remain latent (Olson, 1965). By drawing from the individualistic-rationalistic premises of Olson's (1965) incentive theory the capture theory posits that regulation favours regulatees and not the public interest as a whole. It first emerged in the field of utility regulation with the Chicago school of regulation in an attempt to determine under which conditions regulators favour large/incumbents against small/new comers (Bernstein, 1977, Huntington, 1952) or firms against consumers (Peltzman, 1976, Peltzman, 1984, Posner, 1974, Stigler, 1971) explaining thus regulation failure. Then its premises spread over by including also legislative policy-making. The actual dynamics whereby private interests are favoured against public ones by decision-makers, depending also whether the latter are democratically elected or not, go from bribes, revolving doors (Dal Bo, 2006), career benefits (Dunleavy, 1991, Wilson, 1980) and budget allocation (Niskanen, 1971), through the (impartial) exchange of information (Carpenter, 2004), to campaign contributions (Denzau and Munger, 1986, Grossman and Helpman, 1996) and information asymmetry (Lohmann, 2003, Lohmann, 1998).

\section{The Public Interest Claim}

Before continuing the discussion on the who question a brief introduction of the analysis conducted in Bernhagen (2012) as well as of the findings drawn is needed. The sample consists of 163 government proposals appeared in the main British and Scottish newspapers in the period 20012007. Each policy proposal is accompanied by a mention of one or more interest groups: firms, business associations, citizens' groups etc. The policy position of the interest groups mentioned in relation to each issue is coded as against, concerned, neutral, insufficient and in favour. Then, the investigators coded whether the proposal was enacted, modified or abandoned. In this case, interest group influence is conceived as the causal relationship between the policy position of interest groups and the change in the policy proposal from a frequentist perspective. For instance, if a certain type of interest group is frequently against policy proposals which were abandoned influence is inferred.

In Bernhagen (2012) a rather puzzling finding is drawn in the analysis of interest group influence in the UK. Indeed, findings show that although policy proposals need the overall support of society to be enacted business is not as influential as the mainstream literature expects. Rather, it is not influential at all comparing to public interests, such as citizens' groups. This might suggest that the private interest claim introduced above, which has been paradigmatic in political science in the last four decades, does not apply to the UK. This finding is in line with recent works (Grossmann, 2012, Trumbull, 2012) in interest representation which emphasise the role public interests play in contemporary democracies bringing the public interest claim back into the spotlight in political science.

What I label the public interest claim rests on two main accounts of interest representation and their successive developments: the pluralist account in the form of Truman's (1959) disturbance theory and the traditional public interest theory prevalent in the 1960s (Christensen, 2010, Croley, 2008, den Hertog, 1999). Building on Bentley (1908) Truman (1959) argues that any modern society is a mosaic of interest groups. Interest groups mobilise easily and individuals freely flow from a group to another in a fluid manner. Building on Truman's (1959) work the traditional public interest theory prevalent up to the 1970 s conceives regulation as conducive to the public interest: government is instrumental to deal with the flaws of the market (Levine and Forrence, 1990, 
Mitnick, 1980). Attention on this account has recently revamped in several fields. For instance, in the new regulatory state policy-makers arguably tend to embed Pareto-efficient regulation in legitimate social purposes (Caporaso and Tarrow, 2009). Another account of interest representation claiming that decision-makers further the public interest is the literature on congressional voting behaviour with its concept of anticipated reactions (Arnold, 1992, Bailey, 2001, Denzau and Munger, 1986, Verdier, 1995). The argument is that as long as latent support on an issue is present amongst voters and someone is eager to mobilise that support legislators will represent the public interest. In conclusion, this claim argues that regardless whether decisionmakers are elected office-seeking legislators or Burkean regulators they will represent the public good.

\section{Bringing the What, the When and the How Questions into the Analysis of Interest Group Influence}

As seen, great attention has been paid by the literature on the who question. Nonetheless, the same amount of attention should be paid also to other aspects of interest group influence, such as on what interest groups exert influence, when and how they do so. Those three questions have hitherto received scattered attention on the part of different scholarships, such as the literature on comparative public policy, regulation studies and the American traditional literature on interest group politics. Nonetheless, although some recent works on interest group influence have focused on those aspects (in a separate way) too little attention has been paid to those questions in the study of influence. This work aims to demonstrate that not only are those questions of crucial relevance per se but also that they bear theoretical and empirical implications on the who question.

\section{The How Question: the Second Face of Power}

The two faces of power famously introduced by Bachrach and Baratz (1962) find their roots in the traditional debate between pluralists and elitists in the American social sciences of the 1950s and 1960s. For historical reasons and, especially, due to the analytical ease, only the behaviouralist conceptualization introduced by pluralism has been transposed into contemporary interest group politics (Baumgartner et al., 2009, Klüver, 2013, Kluver, 2011, Yackee and Yackee, 2006, Yackee, 2004, Yackee, 2006, Mahoney, 2007). In fact, what Dür (2008) labels the preference attainment approach, namely the analysis of influence as the investigation of whether and to what extent the final policy outcome moves towards the societal actors' preferences, dominates the literature. That approach usually takes the form of large $\mathrm{N}$ studies which rely on a frequentist mode of causal inference (Goldthorpe, 2001). Influence is conceived as the causal nexus between the interest group action and the policy change under analysis for which evidence is found in how frequently the latter occurs after the former. Bernhagen (2012) represents an exemplar application of such a conceptualization of interest group influence.

Nonetheless, as fiercely argued by elitists, such a component of influence represents only the tip of the iceberg. Stemming from a criticism of the pluralists who start 'their structure at the mezzanine without showing us a lobby' (Kaufman and Jones, 1954 p.207) this work urges scholars to consider what Bachrach and Baratz (1962) terms the second face of power. In other words, often influence does not underpin an action which leads to a policy change: it should also be conceived as a non-event (Lowery, 2013). In this vein, I argue that the analysis of influence should also account for the proximity of actors' preferences from the initial policy output, regardless the final one. Accordingly, the dependent variable of the analysis below is no longer the change in policy output as in the original analysis but the proximity of actors' preferences from the initial policy output. In other words, if a policy proposal is in line with business preferences I assume that a certain degree of influence has been exerted on decision-makers. Although acknowledging the risk of confusing influence with luck (Barry, 1980, Lowery, 2013) the causal link between policy change and the action of interest groups which underpins influence in the traditional approaches based on preference attainment is purely frequentist as well, as underlined above (Goldthorpe, 2001). On top of that, this work does not aim at exhaustiveness nor conclusiveness. Rather, it aims to pave the way for a more nuanced debate on interest group influence in a provocative fashion. 


\section{The What and the When Questions: Issue Salience and the Policy Cycle Stage}

Building on various scholarships I argue that the investigation of interest group influence, especially in the conceptualization proposed in this section, must include also considerations on the type of policy and the stage of the policy cycle. The literature on agenda setting emphasises that issues are usually characterized by attention of few and apathy of many (Baumgartner and Jones, 2009). In line also with the public choice theory, especially in its new developments (Lohmann, 2003, Lohmann, 1998), this information asymmetry is at the very basis of regulatory capture, a situation where business exerts a subtle influence over decision-makers. Agreement prevails also in regulation studies on how policy makes politics, namely on how the type of policy determines the interaction between societal actors and public authority (Lowi, 1964, Wilson, 1980). What determines the passage from a mode of politics dominated by business (quiet politics in Culpepper, 2011) to one in which politicians care about the electorate (in noisy politics, Culpepper, 2011 ) is issue salience. Indeed, when an issue gains media and public attention that information asymmetry fades away and legislators tend to favour public interests moved by electoral considerations (Wilson, 1980, Yackee and Yackee, 2006, Denzau and Munger, 1986). As a conclusion, the following hypothesis is formulated:

$\mathrm{H} 1$ : Policy outputs are more often in line with business preferences where issue salience is low

What Baumgartner and Jones (2009) term the systems of limited participation literature and Van Waarden (1992) includes into the literature of policy networks finds its theoretical roots in the elitist approach to social sciences as well as in the literature on capture mentioned above. This literature concentres particularly on business power. The argument is that decision-making is compartmentalised into secluded policy subsystems where business monopolises agenda setting due to its importance for the national economy (Lindblom, 1977) or to more material exchanges, such as career benefits (Dunleavy, 1991, Wilson, 1989) and/or campaign contributions (Grossman and Helpman, 1996, Denzau and Munger, 1986). Accordingly, business predominance in the earlier stages of policy formulation is hypothesised:

$\mathrm{H} 2$ : Policy outputs in the earlier stages of policy formulation are more often in line with business preferences

\section{Understanding the Accent of the (Un)heavenly Chorus}

This work investigates a way interest groups influence decision-makers which is complementary but not inferior to the one usually analysed by the literature by using an alternative approach to the analysis of interest group influence. The latter is arguably more appropriate to analyse what Bachrach and Baratz (1962) call the second face of power. This is in contrast with the preference attainment approach common in the literature, theoretically and analytically suitable for the analysis of the first face of power. As seen above, those two approaches underpin two different but complementary conceptualizations of influence which in turn derive from the traditional debate between sociological elitism (Hunter, 1953, Schulze, 1958, Bachrach and Baratz, 1962) and political science pluralism (Truman, 1959, Polsby, 1960, Dahl, 1966) in American social sciences. On top of that, I argue for the necessity to focus on the type of policy as well as the stage of the policy cycle on which influence is exerted.

Table 1 illustrates the findings of the regression model for the ordinal dependent variable which measures whether business policy position is against, concerned about, neutral to or in favour a policy proposal, as operationalised in Bernhagen (2012). The variable measuring issue salience is also taken from Bernhagen (2012), who, in line with the literature on interest group influence (Gormley, 1986, Yackee and Yackee, 2006, Yackee, 2004, Yackee, 2006), measures issue salience through media salience with the number of articles mentioning the policy proposal in LexisNexis and Financial Times.

(Table 1) 
As for the policy cycle stage, I use the variable accounting for the type of policy proposal already present in Bernhagen (2012) dataset. In fact, the policy proposal type variable have four categories: public attention, formal review, recommendation and policy proposal. Although they all can be reconciled with the policy formulation stage of the policy cycle they can be placed onto a temporal continuum from public attention through formal reviews and recommendations to policy proposals. I aggregate these four values into a dummy variable for the earlier stages: public attention and formal review assume value 1 whereas recommendation and policy proposal value 0 .

Along with those variables two control variables are included: government change and policymakers' preferences. The reason for the former is to test whether partisanship matters with respect to business influence. Policymakers' commitment is also included: in Bernhagen (2012) dataset a variable measuring the commitment of policy-makers to policy proposals through the data from the Comparative Manifesto Project is present. This is to test whether in line with the traditional public interest theory prevalent until the 1970s once legislators, being office-seeking legislators (Denzau and Munger, 1986) or Burkean regulators (Levine and Forrence, 1990), commit to a piece of legislation they maintain such a commitment.

As illustrated in Table 1, the hypotheses formulated above find empirical support: both issue salience and the stage of the policy cycle are associated with the correspondence between business policy position and the policy proposal. As the quantities of interest simulated with the software package Clarify (King et al., 2000) show, if a policy proposal is in the earlier stages of policy formulation the probability it is in line with business preferences is 56 per cent $(+-10$ per cent) compared with 31 percent (+-10 per cent) in the case the policy proposal is in later stages: the probability increases by 25 per cent. Likewise, if a policy proposal is salient the probability it is in line with business preferences is 15 per cent (+-10 per cent) whereas when the proposal is not salient the probability increases by 23 per cent. As a consequence, if interest group influence is investigated in the alternative way proposed in this work empirical regularities linking business policy positions with policy proposals on those issues which are under the radar of the media and the public opinion are found. Furthermore, the same holds true for the earlier stages of policy formulation. As for the control variables, none of them is significant demonstrating that partisanship and more specifically the political agenda of parties are not relevant.

\section{Conclusion}

In this work I complement the analysis Bernhagen (2012) conducts on interest representation in British politics. That analysis depicts an indulgent picture of the situation in the UK where legislators listen to the society as a whole and, more importantly, where citizens and not business rule in politics. Unfortunately, that is only half of the story. Indeed, the mainstream literature on interest group politics overlook all those dynamics which belong to what Bachrach and Baratz (1962) call the second face power. The theoretical and analytical monopoly of the behavioral conceptualization of power rooted in the mainstream literature leads researchers to forget that 'politics is about who gets what, when and how' (Lasswell, 1936): the what, the when and the how questions are usually neglected.

By relying on the theoretical premises of sociological elitism I introduce an alternative approach to influence, which allows the researcher to detect the second face of power, in counterposition to the mainstream approach of preference attainment, which is more appropriate for the first face of power. In doing so, I find preliminary evidence that the policy cycle stage and issue salience matter. By relying on the same frequentist mode of causal inference the mainstream literature on interest group influence uses I would conclude that business dominates policy-making during its most crucial phase, namely when policies are formulated, and where the media and public opinion do not pay attention. Accordingly, I would claim that aloof from the picture of British politics coming from the analysis in Bernhagen (2012), 'the heavenly chorus [still] sings with a strong upper class accent' (Schattsschneider, 1975 p.35). 
Tables

\begin{tabular}{|c|c|c|}
\hline Business & Model 1 & Model 2 \\
\hline Earlier Stages & $0.653^{* *}$ & $0.670^{* *}$ \\
\hline Salience & $\begin{array}{l}-0.00843^{\star * *} \\
(0.00251)\end{array}$ & $\begin{array}{l}-0.00838^{* * *} \\
(0.00254)\end{array}$ \\
\hline $\begin{array}{l}\text { Policymakers' } \\
\text { Commitment }\end{array}$ & & 0.00900 \\
\hline Government Change & & $\begin{array}{l}(0.0528) \\
0.132 \\
(0.511)\end{array}$ \\
\hline cut1 & & \\
\hline Constant & $\begin{array}{l}-0.767^{\star * *} \\
(0.174)\end{array}$ & $\begin{array}{l}-0.728^{* * *} \\
(0.228)\end{array}$ \\
\hline cut2 & & \\
\hline Constant & $\begin{array}{l}-0.307^{*} \\
(0.163)\end{array}$ & $\begin{array}{l}-0.269 \\
(0.224)\end{array}$ \\
\hline cut3 & & \\
\hline Constant & $\begin{array}{l}-0.0852 \\
(0.162)\end{array}$ & $\begin{array}{l}-0.0472 \\
(0.227)\end{array}$ \\
\hline cut4 & & \\
\hline Constant & $\begin{array}{l}0.290^{*} \\
(0.162)\end{array}$ & $\begin{array}{l}0.329 \\
(0.228)\end{array}$ \\
\hline Observations & 85 & 85 \\
\hline
\end{tabular}




\section{References}

ARNOLD, R. D. 1992. The Logic of Congressional Action, Yale, Yale University Press.

BACHRACH, P. \& BARATZ, M. S. 1962. Two Faces of Power. The American Political Science Review, 56, 947-952.

BAILEY, M. 2001. Quiet Influence: The Representation of Diffuse Interests on Trade Policy, 198394. Legislative Studies Quarterly, 26, 45-80.

BARRY, B. 1980. Is It Better To Be Powerful or Lucky? Part I. Political Studies, 28, 183-194.

BAUMGARTNER, F. R., BERRY, J. M., HOJNACKI, M., LEECH, B. L. \& KIMBALL, D. C. 2009. Lobbying and Policy Change: Who Wins, Who Loses, and Why, University of Chicago Press.

BAUMGARTNER, F. R. \& JONES, B. D. 2009. Agendas and Instability in American Politics, Second Edition, University of Chicago Press.

BENTLEY, A. F. 1908. The process of government; a study of social pressures, The University of Chicago press.

BERNHAGEN, P. 2012. Who Gets What in British Politics - and How? An Analysis of Media Reports on Lobbying around Government Policies, 2001-7. Political Studies, 60, 557-577.

BERNSTEIN, M. H. 1977. Regulating Business by Independent Commission, Greenwood Press.

CAPORASO, J. A. \& TARROW, S. 2009. Polanyi in Brussels: Supranational Institutions and the Transnational Embedding of Markets. International Organization, 63, 593-620.

CARPENTER, D. P. 2004. Protection without Capture: Product Approval by a Politically Responsive, Learning Regulator. The American Political Science Review, 98, 613-631.

CHRISTENSEN, J. G. 2010. Public Interest Regulation Reconsidered: From Capture To Credible Commitment. Jerusalem Papers in Regulation \& Governance, 19.

CROLEY, S. P. 2008. Regulation and Public Interests: The Possibility of Good Regulatory Government, Princeton, New Jersey, Princeton University Press.

CULPEPPER, P. D. 2011. Quiet Politics and Business Power: Corporate Control in Europe and Japan. Cambridge: Cambridge University Press.

DAHL, R. 1966. Who Governs? Democracy and Power in an American City.

DAL BO, E. 2006. Regulatory Capture: A Review. Oxford Review of Economic Policy, 22, 203-225.

DEN HERTOG, J. 1999. General Theories of Regulation. Utrecht University.

DENZAU, A. T. \& MUNGER, M. C. 1986. Legislators and Interest Groups: How Unorganized Interests get Represented. The American Political Science Review, 80, 89-106.

DÜR, A. 2008. Measuring Interest Group Influence in the EU: A Note on Methodology. European Union Politics, 9, 559-576.

DUNLEAVY, P. 1991. Democracy, Bureaucracy and Public Choice, New York, New York, Harvester/Wheatsheaf.

GOLDTHORPE, J. H. 2001. Causation, Statistics, and Sociology. European Sociological Review, 17, 1-20.

GORMLEY, W. T., JR. 1986. Regulatory Issue Networks in a Federal System. Polity, 18, 595-620.

GROSSMAN, G. M. \& HELPMAN, E. 1996. Electoral Competition and Special Interest Politics. The Review of Economic Studies, 63, 265-286.

GROSSMANN, M. 2012. The Not-So-Special Interests: Interest Groups, Public Representation, and American Governance, Stanford University Press.

HUNTER, F. 1953. Community Power Structure: A Study of Decision Makers, University of NORTH CAROLINA Press.

HUNTINGTON, S. P. 1952. The Marasmus of the ICC: The Commission, the Railroads, and the Public Interest. The Yale Law Journal, 61, 467-509.

KAUFMAN, H. \& JONES, V. 1954. The Mystery of Power. Public Administration Review, 14.

KING, G., TOMZ, M. \& WITTENBERG, J. 2000. Making The Most Of Statistical Analyses: Improving Interpretation And Presentation. American Journal of Political Science 44, 347361.

KLÜVER, H. 2013. Lobbying in the European Union: Interest Groups, Lobbying Coalitions, and Policy Change, Oxford, United Kingdom, Oxford University Press.

KLUVER, H. 2011. The contextual nature of lobbying: Explaining lobbying success in the European Union. European Union Politics, 12, 483-506. 
LASSWELL, H. D. 1936. Politics; who gets what, when, how, Whittlesey house.

LEVINE, M. E. \& FORRENCE, J. L. 1990. Regulatory Capture, Public Interest, and the Public Agenda: Toward a Synthesis. Journal of Law, Economics, \& Organization, 6, 167-198.

LINDBLOM, C. 1977. Politics and markets: the world's political economic systems, Basic Books.

LOHMANN, S. 1998. An Information Rationale for the Power of Special Interests. The American Political Science Review, 92, 809-827.

LOHMANN, S. 2003. Representative Government and Special Interest Politics: (We Have Met the Enemy and He is Us). Journal of Theoretical Politics, 15, 299-319.

LOWERY, D. 2013. Lobbying influence: Meaning, measurement and missing. Interest Groups \& Advocacy, 2, 1-26.

LOWI, T. J. 1964. At the pleasure of the mayor : patronage and power in New York City, 18981958, New York, Free Press of Glencoe.

MAHONEY, C. 2007. Lobbying Success in the United States and the European Union. Journal of Public Policy, 27, 35.

MITNICK, B. M. 1980. The political economy of regulation : creating, designing, and removing regulatory forms, New York, Columbia University Press.

NISKANEN, W. A. 1971. Bureaucracy and representative government, Chicago, Aldine.

OLSON, M. 1965. The Logic of Collective Action: Public Goods and the Theory of Groups, Harvard University Press.

OLSON, M. 1982. The Rise and Decline of Nations, Yale University Press.

PELTZMAN, S. 1976. Towards a More General Theory of Regulation. Journal of Law and Economics, 19 211-240.

PELTZMAN, S. 1984. Constituent Interest and Congressional Voting. Journal of Law and Economics, 27, 181-210.

POLSBY, N. W. 1960. How to Study Community Power: The Pluralist Alternative. The Journal of Politics, 22, 474-484.

POSNER, R. A. 1974. Theories of Economic Regulation. Bell Journal of Economics and Management Science, 5, 335-358.

SCHATTSCHNEIDER, E. E. 1975. The semisovereign people: a realist's view of democracy in America, Dryden Press.

SCHULZE, R. O. 1958. The Role of Economic Dominants in Community Power Structure. American Sociological Review, 23, 3-9.

STIGLER, G. J. 1971. The Theory of Economic Regulation. The Bell Journal of Economics and Management Science, 2, 3-21.

TRUMAN, D. B. 1959. The governmental process: political interests and public opinion, Knopf.

TRUMBULL, G. 2012. Strength in Numbers: The Political Power of Weak Interests, Harvard University Press.

VAN WAARDEN, F. 1992. The historical institutionalization of typical national patterns in policy networks between state and industry. European Journal of Political Research, 21, 131-162.

VERDIER, D. 1995. Democracy and International Trade: Britain, France, and the United States, 1860-1990, Princeton University Press.

WILSON, J. Q. 1980. Politics of regulation, New York, New York, Basic.

WILSON, J. Q. 1989. Bureaucracy : what government agencies do and why they do it, New York, Basic Books.

YACKEE, J. W. \& YACKEE, S. W. 2006. A Bias Towards Business? Assessing Interest Group Influence on the U.S. Bureaucracy. The Journal of Politics, 68, 128-139.

YACKEE, S. W. 2004. Sweet-Talking the Fourth Branch: The Influence of Interest Group Comments on Federal Agency Rulemaking. Journal of Public Administration Research and Theory, 16, 103-124.

YACKEE, S. W. 2006. Assessing Inter-Institutional Attention to and Influence on Government Regulations. British Journal of Political Science, 36, 723-744. 